Chirurgia (2017) 112: 229-243

No. 3, May - June

Copyright@ Celsius

http://dx.doi.org/10.21614/chirurgia.112.3.229

\title{
The Romanian National Program for Liver Transplantation - 852 Procedures in 815 Patients over 17 Years (2000-2017): A Continuous Evolution to Success
}

\author{
Irinel Popescu' ${ }^{1,2}$, Mihnea Ionescu', Vladislav Brașoveanu', Doina Hrehoreț, ${ }^{1,2}$, Narcis Copca², Cristian Lupașcu ${ }^{3}$, \\ Florin Botea', Bogdan Dorobanțu1, Sorin Alexandrescu', Mihai Grigorie', Emil Matei', Radu Zamfir', Vasile Lungu', \\ Dana Tomescu', Gabriela Droc ${ }^{1}$, Daniela Ungureanu', Ruxandra Fota', Grațiela Manga', Mihai Popescu', Laura Popa², \\ Liana Gheorghe', Speranța lacob1', Corina Pietrăreanu1', Mariana Mihailă', Laurențiu Micu1', Sanda Constantinescu1', \\ Cristian Gheorghe', Bogdan Cotruta1, Ioana Lupescu', Mugur Grasu', Mirela Boroș', Radu Dumitru', Mihai Toma', \\ Liliana Pâslaru', Laura Vlad', Ileana Constantinescu1', Ileana Dima1', Vlad Herlea', Gabriel Becheanu', Cătălin Pecheanu', \\ Daniela Sasalovici'
}

\footnotetext{
"Dan Setlacec" Center of General Surgery and Liver Transplantation, Fundeni Clinical Institute, Bucharest, Romania 2"Sfanta Maria" Clinical Hospital, II ${ }^{\text {nd }}$ Clinic of Surgery, Bucharest, Romania

3"Sfantul Spiridon" Emergency Clinical Hospital, IInd Clinic of Surgery, Iași, Romania
}

Corresponding author: Irinel Popescu, MD, FACS, FEBS Professor of Surgery "Dan Setlacec" Center of General Surgery and Liver Transplantation, Fundeni Clinical Institute Sos. Fundeni, 258, 022328, Bucharest, Romania E-mail: irinel.popescu@icfundeni.ro

\section{Abbreviations:}

ECD: extended criteria donors

DDLT: deceased donor liver

transplantation

$H B V$ : hepatitis $B$ virus

HCV: hepatitis $C$ virus

HCC: hepatocellular carcinoma

LDLT: living donor liver transplantation LT: liver transplantation

MELD: model of end-stage liver disease PELD: pediatric end-stage liver disease

Received: 10.04 .2017

Accepted: 28.04.2017

\section{Rezumat \\ Programul National din România pentru Transplant hepatic - 852 de proceduri la 815 pacienți în 17 ani (2000-2017): o evoluție continuă către succes}

Introducere: Transplantul hepatic a devenit o metodă terapeutică standardizată pentru bolile hepatice cronice în stadii terminale, cu peste 20.000 de proceduri anual la nivel mondial.

Material şi metodă: În perioada aprilie 2000 şi aprilie 2017, în România au fost efectuate 852 proceduri de transplant hepatic la 817 pacienți. Raportul bărbați/femei a fost de 487/330, iar raportul adulți/copii de 753/64. Vârsta medie a fost de 46 ani (mediana 50; interval 7 luni -68 ani). Principala indicație de transplant a fost ciroza VHB (230 pacienți; 28,2\%), carcinomul hepatocelular (173 pacienți; 21,2\%), şi ciroza VHC (137 pacienți; 16,8\%). Au fost analizați următorii parametrii: timpul pe lista de aşteptare, indicațiile de transplant, datele demografice ale donatorilor şi receptorilor, caracteristicile grefelor hepatice, procedurile chirurgicale şi rezultatele postoperatorii imediate şi la distanță.

Rezultate: Transplantul hepatic de la donator decedat a fost realizat la 682 pacienți (83,9\%): cu grefă întreagă la 662 pacienți (81\%), grefă împărțită la 16 pacienți $(2,3 \%)$, grefă redusă la 2 pacienți $(0,2 \%)$, şi transplant domino la 1 pacient $(0,1 \%)$. 
Transplantul hepatic de la donator în viață a fost realizat la 135 pacienți (16,5\%): cu hemificat drept la 93 pacienți $(11,4 \%)$, secțiune laterală stângă la 28 pacienți $(3,4 \%)$, hemificat stâng la 8 pacienți (1\%), hemificat stâng şi lob caudat la 4 pacienți $(0,5 \%)$, şi cu grefă duală la 2 pacienți $(0,2 \%)$. Rata de morbiditate majoră a fost de 31,4\% (268 pacienți), iar mortalitatea perioperatorie de 7,9\% (65 pacienți). Rata de retransplantare a fost de 4,3\% (35 pacienți): 27 transplanturi cu grefă întreagă, 3 cu ficat redus, 3 cu ficat împărțit, şi 2 cu grefă de la donator în viață. Supraviețuirea la 1-, 3-, şi 5 ani a fost de $87,9 \%, 81,5 \%$, şi respectiv 79,1\%. Mortalitatea pe lista de aşteptare la 1-, 3-, şi 5 ani a scăzut semnificativ de-alungul timpului de la $31,4 \%, 54,1 \%$ şi $63,5 \%$, la 4,4\%, $13,9 \%$ şi respectiv $23,6 \%$.

Concluzii: Programul național de transplant hepatic din România tratează toate cauzele specifice de insuficiență hepatică cronică şi acută, şi de tumori hepatice, atât la adulți cât şi la copii, folosind toate tehnicile chirurgicale, cu rezultate postoperatorii optime. Dezvoltarea continuă a programul de-alungul timpului a dus la scăderea mortalității pe lista de aşteptare.

Cuvinte cheie: transplant hepatic, centru de excelenta in transplant, experiență națională

\begin{abstract}
Background: Liver transplantation (LT) has become an established treatment for end-stage liver disease, with more than 20.000 procedures yearly worldwide. The aim of this study was to analyze the results of Romanian National Program of LT.

Methods: Between April 2000 and April 2017, 817 pts received 852 LTs in Romania. Male/female ratio was $487 / 330$, while adult/pediatric ratio was $753 / 64$, with a mean age of 46 years (median 50 yrs; range 7 months - 68 yrs). Main LT indications were HBV cirrhosis (230 pts; 28.2\%), HCC (173 pts; $21.2 \%$ ), and HCV cirrhosis (137 pts; 16.8\%). Waiting time and indications for LT, patient and donor demographics, graft features, surgical procedures, and short and long-term outcomes were analyzed.

Results: DDLT was performed in 682 pts (83.9\%): whole LT in 662 pts (81\%), split LT in 16 pts (2.3\%), reduced LT in 2 pts $(0.2 \%)$, and domino LT in 1 pts (0.1\%). LDLT was performed in 135 pts (16.5\%): right hemiliver in $93 \mathrm{pts}(11.4 \%)$, left lateral section in $28 \mathrm{pts}(3.4 \%)$, left hemiliver in $8 \mathrm{pts}(1 \%)$, left hemiliver with segment 1 in 4 pts $(0.5 \%)$, and dual graft LDLT in 2 pts $(0.2 \%)$. Overall major morbidity rate was $31.4 \%$ (268 pts), while perioperative mortality was $7.9 \%$ (65 pts). Retransplantation rate was 4.3\% (35 pts): 27 whole LTs, 3 reduced LTs, 3 split LTs, and 2 LDLT. Long-term overall 1-, 3-, and 5-year estimated survival rates for patients were $87.9 \%, 81.5 \%$, and $79.1 \%$, respectively. One-, 3 -, and 5-year overall mortality on waiting list also decreased significantly over time from $31.4 \%, 54.1 \%$ and $63.5 \%$, to $4.4 \%, 13.9 \%$ and $23.6 \%$, respectively.

Conclusions: The Romanian National program for liver transplantation addresses all causes of acute and chronic liver failure or liver tumors in adults and children, using all surgical techniques, with good long-term outcome. The program constantly evolved over time, leading to decreased mortality rate on the waiting list.
\end{abstract}

Key words: liver transplantation, high-volume transplantation center, national experience

\section{Introduction}

Liver transplantation (LT) has become an established treatment for end-stage liver disease, with more than 20.000 procedures yearly worldwide (1). Survival rates after LT have significantly improved due to refinement in surgical techniques, excellent anesthetic management, aggressive nursing care, and prompt detection and treatment of complica- 
tions. The request for LT continues to increase while the donor pool size remains inadequate.

\section{Evolution of Liver Transplantation in Romania}

In Romania, after several experimental LT carried out during the second half of the $20^{\text {th }}$ century, the first (unsuccessful) LT was performed in 1997 by I. Popescu et al at Fundeni Clinical Institute in Bucharest. In 2000, the first successful LT (with whole graft) was carried out by the same surgical team, followed by the first living donor liver transplantation (LDLT) (successful) later the same year (2). By the end of 2006 the transplant center reached 20 LTs per year, the minimum number recommended for satisfactory results $(3,4,5,6)$. Later on, in 2011 , the center became a high-volume center exceeding 50 LTs per year $(3,4,5,6)$. Based on professionals and expertise from the main transplantation center (Fundeni Clinical Institute) a second LT center was open at "Sfanta Maria" Hospital in Bucharest (2014), and a third one at "Sfantul Spiridon" Hospital in Iaşi (2016).

\section{Material and Methods}

\section{Recipients}

From April 2000 to April 2017, 817 pts who received 852 LTs in Romania were retrospectively analyzed. Out of these patients, 819 (96.1\%) were operated at Fundeni Clinical Institute in Bucharest, 35 pts (4.1\%) at "Sfanta Maria" Clinical Hospital in Bucharest, and 2 pts $(0.2 \%)$ at "Sfantul Spiridon" Hospital in Iasi. All recipients were regularly followed-up by a multidisciplinary team. Main medical records were collected prospectively and data were completed by retrospective review.

All candidates for LT were evaluated using standardized criteria based on general status, clinical symptoms and investigations results of liver disease, MELD/PELD score, and liver tumor features (when the case). These candidates were preoperatively evaluated by a multidisciplinary transplant team that included a surgeon, hepatologist, pediatrician, anesthesiologist, psychologist, during weekly meetings. Patients with hepatocellular carcinoma (HCC) were preferably within Milan criteria for LT in HCC (7), but those outside these criteria were also considered for LT. Patients with hepatitis B viral-related liver diseases received hepatitis B immunoglobulin and lamivudine prophylaxis after LT. The major postoperative complications were considered at least IIIB class according to Dindo-Clavien et al classification (8). Perioperative mortality included intraoperative and 90-day postoperative deaths.

Patients were divided into 3 groups, in function of the development phase of the main transplantation center: early stage of development as low-volume center defined by up to 20 transplanted pts yearly (Group 1), intermediate stage of mid-volume center (Group 2) defined by 20 to 50 transplanted pts yearly, and advanced stage of high-volume center defined by over 50 transplanted pts yearly $(3,4,5,6)$. Consequently, the groups were as follows: Group 1 included the 96 pts transplanted from April 2000 to December 2006, Group 2 included the 148 pts transplanted from January 2007 to December 2010, and Group 3 included the 404 pts transplanted from January 2011 to April 2017.

\section{Waiting List}

Patients with end-stage liver disease, acute liver failure and/or with hepatic tumors who may benefit from LT were registered on the waiting list according to $\mathrm{ABO}$ blood type, body mass index, degree of medical urgency, ChildPugh score. More recently, each patient received a priority score based on MELD (model of endstage liver disease) score in adults (9) and PELD (pediatric end-stage liver disease) in children. Patients on the waiting list were periodically evaluated and continuously treated; those with the highest scores had priority for transplantation (10). In case of HCC, patients benefited for specific treatment while on waiting list (transarterial chemoembolization, thermal ablation, and/or liver resection) with the purpose to maintain the tumor within Milan Criteria (11) or to downstage it to within these criteria. 


\section{Donors}

Liver grafts for transplantation were harvested from both deceased and living donors. Consequently, a total of 843 donors were recorded.

\section{Deceased Donors}

Potential donors were declared brain dead and investigated according to a standard protocol (12). Informed consent had to be obtained from close relatives. Consequently, 705 donors were harvested ( $74.5 \%$ of the deceased donor pool): 662 of the grafts were used for whole LT, 8 whole grafts and 1 partial graft (segments 4-8) for split LT, 2 whole grafts for reduced LT, 1 whole graft for domino LT, while for retransplantation the following grafts were used: 27 grafts for whole LT, 1 graft and 1 partial graft (left lateral section) for 3 split LT, and 3 grafts for reduced LT. Only 1 donor was non-heart beating.

\section{Extended Criteria Liver Graft Donors}

To increase the donor pool, extended criteria donors (ECD) were accepted since the beginning of LT program. The considered extended criteria were according to international consensus (13): donor-related features (age over 65 yrs, body mass index over $30 \mathrm{~kg} / \mathrm{m}^{2}$ ), factors related to intensive care (ICU stay and ventilation support more than 7 days, hypotension and inotropic support - at least two pressors at any time, highdose dopamine or epinephrine, resuscitated cardiac arrest), liver steatosis (macrosteatosis, more than $30 \%$ but less than $60 \%$ ), biochemical imbalances (hypernatremia over $165 \mathrm{mEq} / \mathrm{L}$ ), liver dysfunction (elevated AST/ALT more than 3 times, total bilirubin over $3 \mathrm{mg} / \mathrm{dl}$ ), cold ischemia time more than 12 hours, viral infections (positive serology for HBV or HCV hepatitis), sepsis-related factors (positive blood culture, meningitis), malignancy risk factors (history of extrahepatic malignancy, low-grade central nervous system tumors), and non-heart beating donors. According to these criteria, 383 marginal grafts were harvested and used.

\section{Other Sources for Liver Grafts}

Other sources for liver grafts were used in 15 pts (1.8\%): methanol-poisoning (4 donors), liver graft trauma (8 donors), benign tumors in liver graft (2 donors) and Takayasu's syndrome (1 donor).

\section{Living Donors}

The potential living donor benefited from a medical and psychiatric assessment using an extensive workup which included Doppler ultrasonography, computed tomography with volumetry, and magnetic resonance cholangiography. The criteria for living donor selection evolved with improved surgical management and accumulated experience. Controversial donors included those with small future remnant liver volume $(<40 \%$ of total liver volume), complex anatomical anomalies of liver vessels and biliary tree, advanced liver steatosis, previous extensive abdominal surgery, significant associated medical illness, hepatitis B surface antigen or hepatitis C antibodypositive; elderly donors over 60 years of age were systematically excluded. Each potential donor was assessed by a multidisciplinary team. Donor safety was the main concern in all cases.

There were 138 living donors (16.4\% of total number of donors): $93 \mathrm{pts}$ donated the right hemiliver, $28 \mathrm{pts}$ the left lateral section, $8 \mathrm{pts}$ the left hemiliver, 4 pts the left hemiliver together with segment 1, 4 pts were harvested for 2 dual graft LDLTs (right hemiliver and left lateral section, and left hemiliver and left lateral section, respectively), while $1 \mathrm{pt}$ donated the left lateral section for a retransplantation after DDLT.

\section{Indication for Liver Transplantation}

LT was indicated in adult and pediatric patients with chronic end stage liver disease (decompensated liver cirrhosis, cholestatic liver, metabolic and vascular liver disease), liver tumors (such as HCC), acute liver failure, or miscellaneous disease (such as adult polycystic liver disease, Caroli's disease). 


\section{Donor-recipient Matching}

Each donor graft was matched to a specific recipient. The main criteria were $\mathrm{ABO}$ blood type compatibility, body mass index and graft weight. ECD grafts were usually allocated to recipients with decompensated liver cirrhosis with low MELD score, and/or HCC. ECD grafts were avoided when possible in case of recipients with significant associated diseases, high MELD score and/or with HCV infection. Additionally, liver grafts from cadaveric donors with age above 50 years were usually avoided in recipients with HCV-related decompensated cirrhosis, with the purpose to avoid early post-transplant HCV recurrence (14). Moreover, LDLT in HCV-infected recipients was generally considered as a life-saving procedure (15). In case of HCC, recipients with tumors within Milan Criteria with controlled disease progression benefited from the same policy as the non-HCC recipients, while recipients with $\mathrm{HCC}$ within Milan Criteria and aggressive disease progression while on waiting list, or those beyond Milan Criteria were usually matched with ECD grafts or grafts harvested from living donors (16).

\section{Surgical Technique}

The surgical techniques for graft harvesting and implantation were standard and described elsewhere $(12,17,18,19)$.

Particularly, in case of orthotopic whole LT, the venous reconstruction of liver graft was recently performed using a modified surgical technique involving triangular cavo-cavostomy (donor's inferior vena cava with a $6-8 \mathrm{~cm}$ vertical slit in its posterior wall was anastomosed in a latero-lateral fashion to the recipient's inferior vena cava with bridged ostia of the hepatic veins trunks together with a 6-8 $\mathrm{cm}$ vertical incision along the anterior wall); this technique replaced the piggy-back technique that was used in early experience. Another particularity is that for biliary reconstruction using choledoco-choledocal anastomosis, consisting in the elimination after early experience of the protection by T-tube biliary drainage.
In case of LDLT, the preferred graft was the right hemiliver without median hepatic vein, with reconstructed venous drainage of the anterior section and/or posterior section in case of segmental veins larger than $5 \mathrm{~mm}$ in diameter.

\section{Immunosuppression}

All patients received immunosuppressive induction, currently based on basiliximab; methylprednisolone was used as protocol during early experience, but lately only in selected cases. Maintenance immunosuppression regimens are currently based mainly on tacrolimus (standard), cyclosporine (alternative to tacrolimus) or sirolimus (in pts transplanted for HCC), in association with mycophenolate mofetil.

\section{Statistical Analysis}

Medical records were explored based on patient demographics, waiting list parameters (indications for LT, blood type, body mass index, MELD/PELD score), graft type, intraoperative parameters (operative time, blood loss, warm and cold ischemia time), short and long-term outcome. Categorical data were analyzed using the Chi-squared test. Continuous data were described as the average and standard deviation, or median and range, and analyzed using Student's t-test. Perioperative mortality included deaths occurred intraoperatively and 1 month postoperatively. Long-term survival was analyzed in patients with more than 1 month follow-up using the Kaplan-Meier method and the Log rank test. A p value of $<0.05$ was considered statistically significant.

\section{Results}

\section{Recipients}

In the overall group ( $817 \mathrm{pts}$ ), the gender ratio was $487 / 330$, the adult/pediatric ratio was $753 / 64$, and the mean age of $46 \mathrm{yr}$ (median 50, range 7 months $-68 \mathrm{yr}$ ).

Recipients with age between 45 and $60 \mathrm{yrs}$ represented the majority (420 pts; $51.4 \%$ ), 


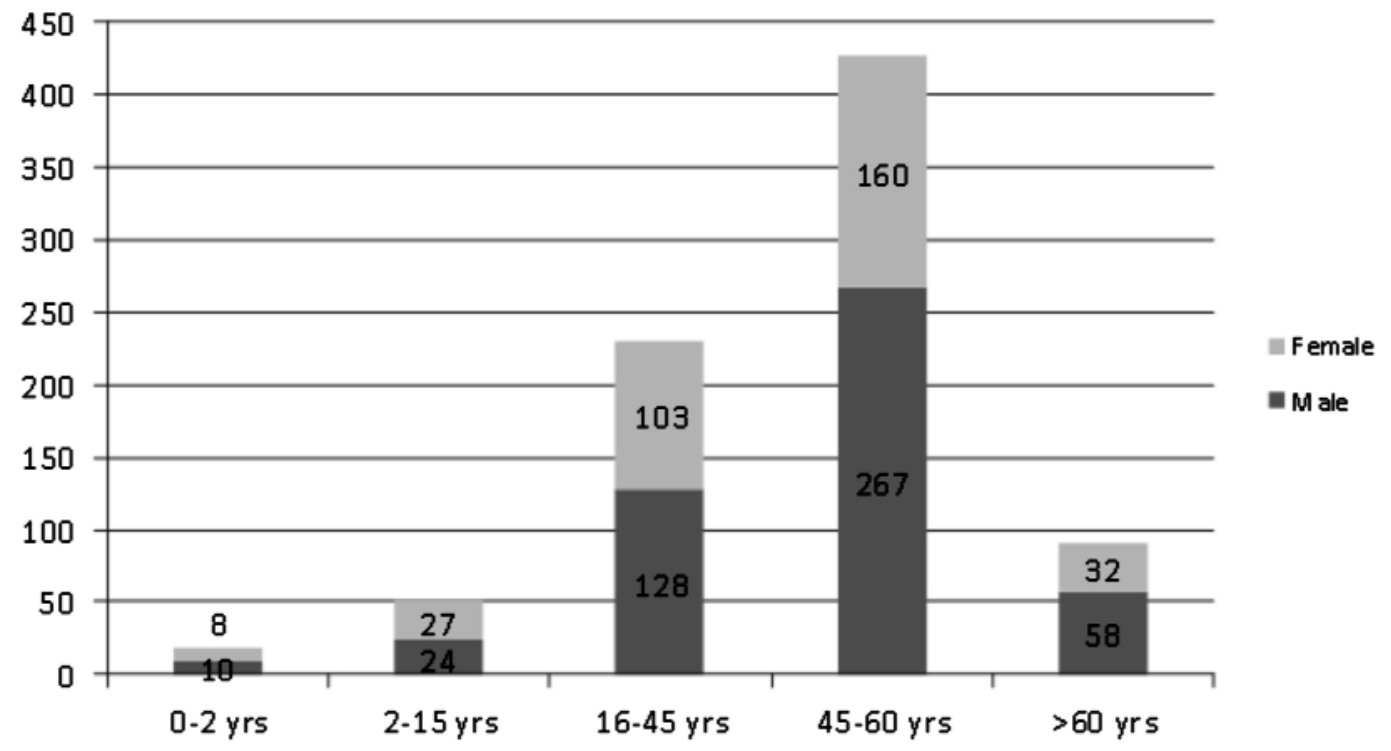

Figure 1. Gender and age distribution of LT recipients.

with a male/female ratio of 267/160 (Fig. 1). The main increase tendency over time was recorded in the age groups of $45-60$ yrs and over 60 yrs (Fig. 2).

\section{Waiting List}

Median waiting time for LT in patients with 0I, AII, BIII, and ABIV blood type was 107, 99, 51, and 45 months before 2011 (Group 1 and
2), and 28, 18, 34, and 20 months after 2011 (Group 3), respectively. One-year overall mortality on the waiting list was $31.4 \%$ before 2011 (Group 1 and 2), and 11.8\% after 2011 (Group 3).

\section{Donors}

\section{Deceased Donors}

Median donor age was 43 yrs (mean 41; range

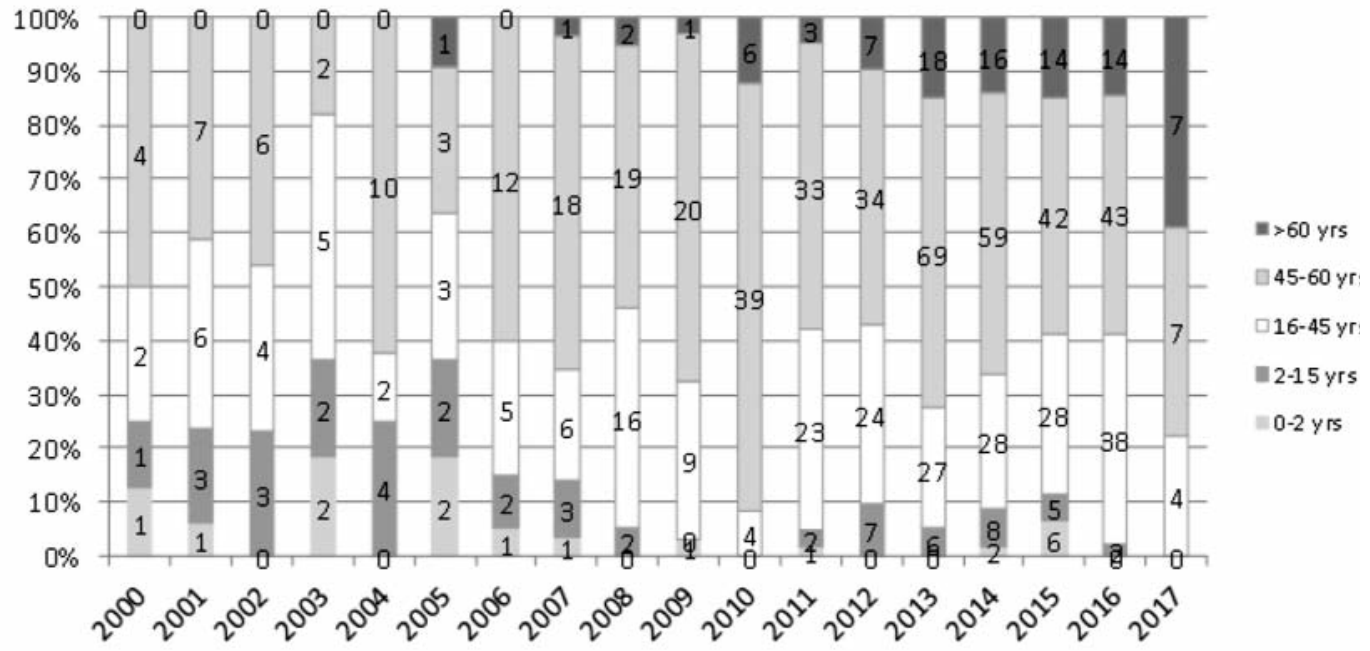

Figure 2. Evolution of age groups in LT recipients 


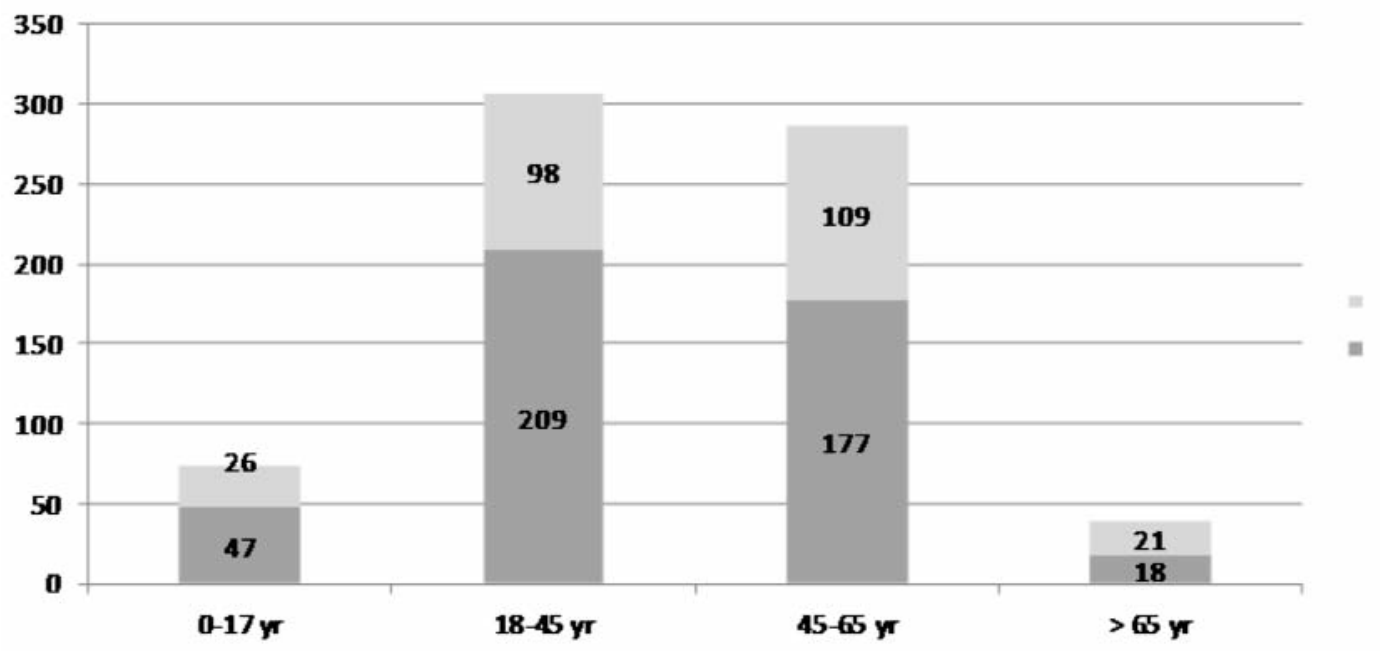

Figure 3. Age and gender distribution of deceased donors

$2-78$, and male/female ratio was 451/254. Donor blood types were as follows: 224 pts were 0I (31.8\%), 324 pts were AII (45.9\%), 106 pts were BIII (15.1\%), and 60 pts were ABIV $(7.2 \%)$.

Among the 705 deceased donors, those with age between 18 and 45 yrs represented the majority (307 donors; 43.5\%), with a male/ female ratio of 209/98 (Fig. 3). The evolution over time in terms of age groups was mainly in favor of 45-60 yrs and over 60 yrs (Fig. 4). The main cause of death in donors was stroke (360 donors; 51.1\%), with an incidence that increased over time, followed by cerebral trauma (217 donors; 30.8\%) (Fig. 5) and polytrauma (80 donors; 11.3\%); other causes (48 donors; 6.8\%) were asphyxiation (15 donors), cerebral tumor (4 donors), resuscitated cardiac arrest (13 donors), intoxication (12 donors), acute hydrocephalus (3 donor), and

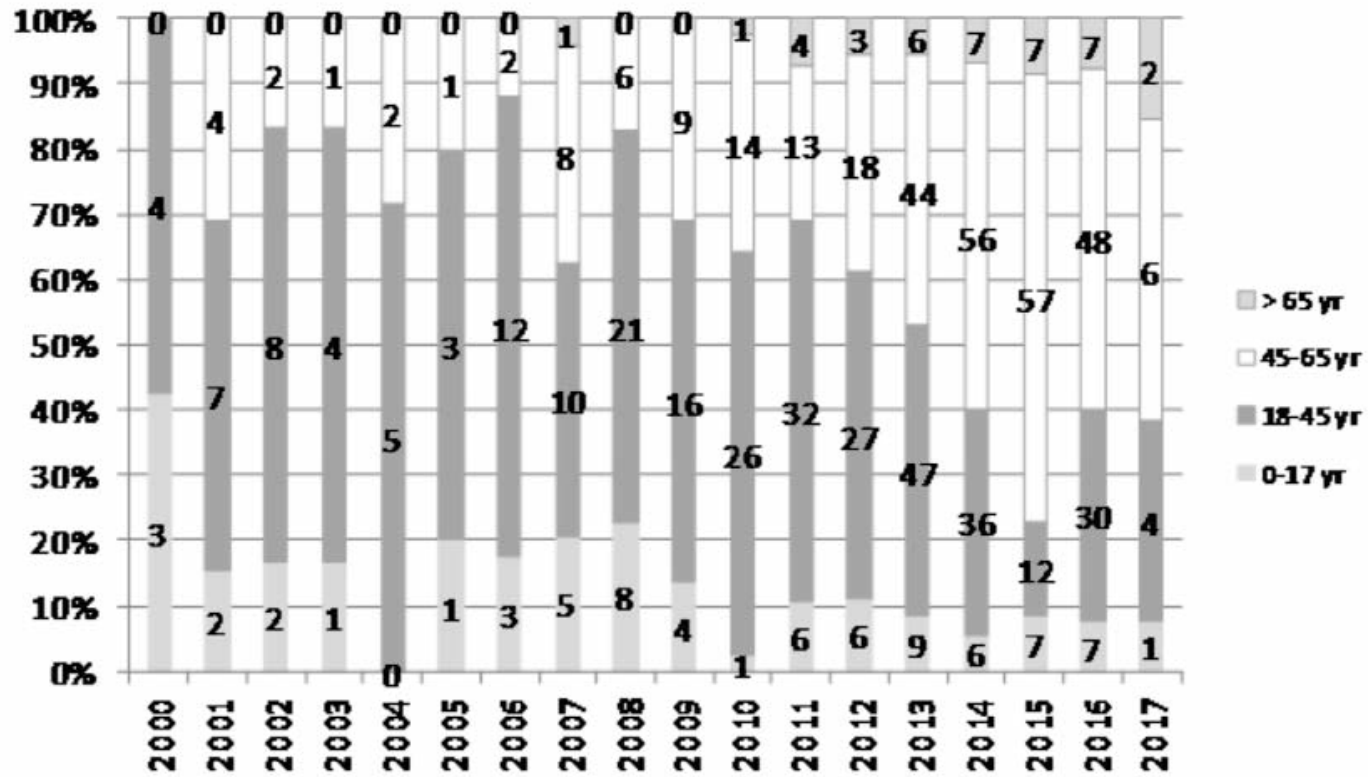

Figure 4. Evolution of deceased donor age groups 


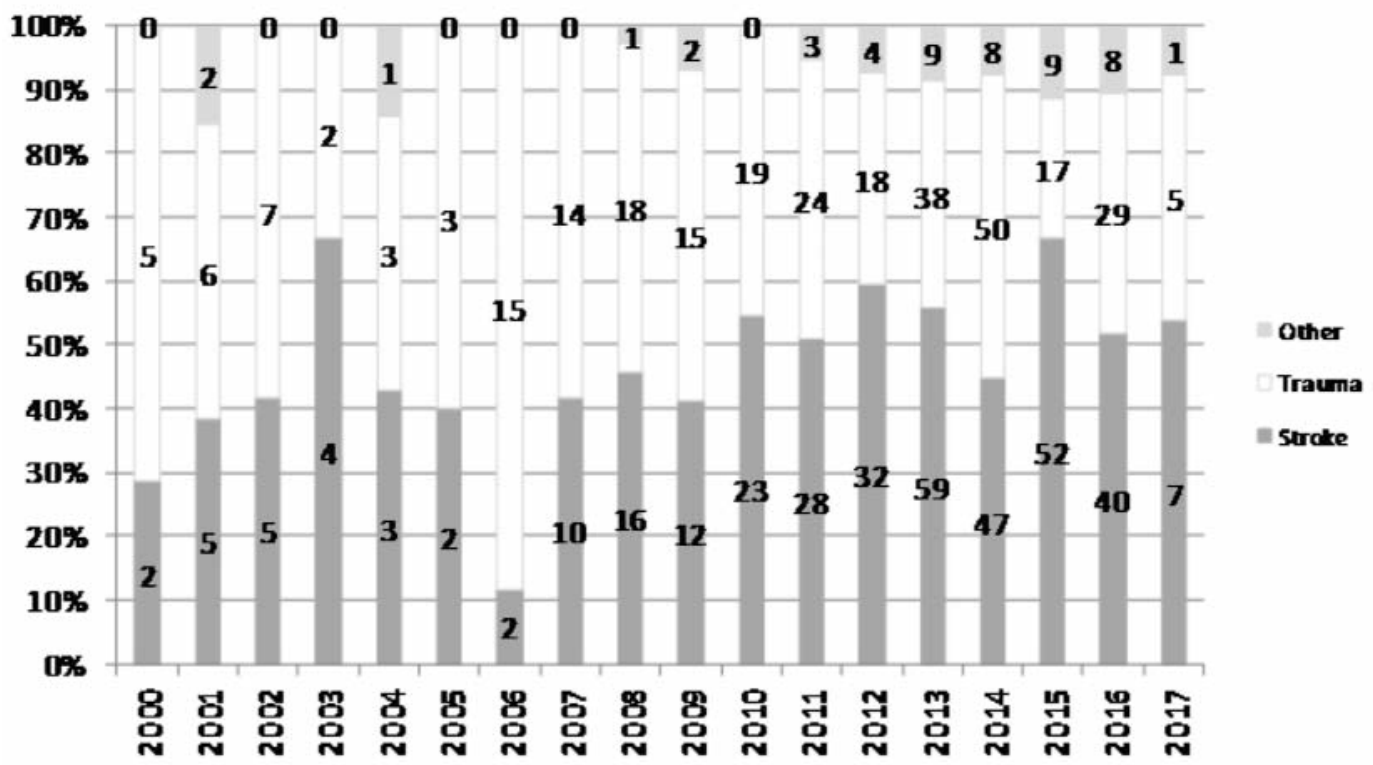

Figure 5. Evolution of causes of death in donors

ruptured aortic aneurysm (1 donor). The median graft weight was $1580 \mathrm{~g}$ (mean 1581; range 415-3150). The median cold ischemia time was 5:35 h (mean 5:42; range 1:20 16:41), while the median warm ischemia time was 0:30 h (mean 0:35; range 0:05 - 05:38).

The ECD grafts represented $54.3 \%$ of the 700 deceased donor LTs (DDLT). The extended criteria found in the 383 deceased donors are presented in Table 1; 138 ECDs (36\%) had multiple such criteria. The main allocation of ECDs was to cirrhotic recipients (228 pts; $59.5 \%$ ), and HCC recipients (96 pts; 25.1\%) (Fig. 6).

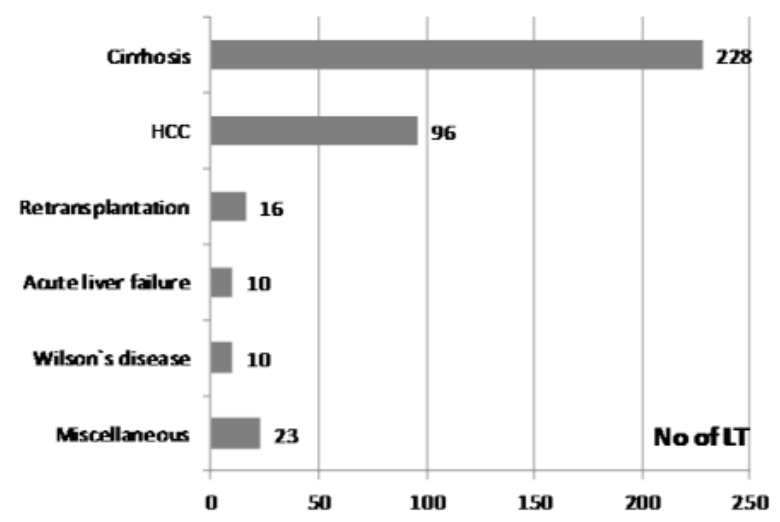

Figure 6. Allocation of liver grafts from extended criteria donor (ECD) in function of cause for liver transplantation (LT)
Table 1. Extended criteria for liver grafts $(\mathrm{N}=373)$

\begin{tabular}{|c|c|c|}
\hline & Extended criteria for liver grafts & No of pts \\
\hline \multirow[t]{2}{*}{$\begin{array}{l}\text { Donor-related } \\
\text { features: }\end{array}$} & Age $>65$ yrs & 46 \\
\hline & Body mass index $>30 \mathrm{~kg} / \mathrm{m}^{2}$ & 23 \\
\hline \multirow[t]{3}{*}{$\begin{array}{l}\text { Factors related } \\
\text { to ICU: }\end{array}$} & $\begin{array}{l}\text { ICU stay and ventilation support } \\
>7 \text { days }\end{array}$ & 43 \\
\hline & $\begin{array}{l}\text { Hypotension and inotropic support } \\
\text { ( } \geq 2 \text { pressors at any time, high-dose } \\
\text { dopamine or epinephrine) }\end{array}$ & 127 \\
\hline & Resuscitated cardiac arrest & 103 \\
\hline Liver steatosis: & Macrosteatosis (>30\% but $\leq 60 \%$ ) & 45 \\
\hline \multirow[t]{2}{*}{$\begin{array}{l}\text { Biochemical } \\
\text { imbalances: }\end{array}$} & $\begin{array}{l}\text { Hypernatremia } \\
\text { (peak serum } \mathrm{Na}>165 \mathrm{mEq} / \mathrm{L} \text { ) }\end{array}$ & 33 \\
\hline & $\begin{array}{l}\text { Liver disfunction } \\
\text { (AST/ALT>3X; BT > 3mg/dl) }\end{array}$ & 7 \\
\hline $\begin{array}{l}\text { Cold ischemia } \\
\text { time }\end{array}$ & $>12$ hours & 1 \\
\hline \multirow[t]{4}{*}{ Viral infections: } & Positive serology for HBV hepatitis & 16 \\
\hline & $\mathrm{AgHBs}(+)$ & 6 \\
\hline & $\mathrm{AgHbc}(+)$ & 9 \\
\hline & Positive serology for HCV hepatitis & 1 \\
\hline $\begin{array}{l}\text { Sepsis-related } \\
\text { factors: }\end{array}$ & Sepsis with positive blood culture & 3 \\
\hline $\begin{array}{l}\text { Malignancy } \\
\text { risk factors: }\end{array}$ & History of extrahepatic malignancy & 1 \\
\hline $\begin{array}{l}\text { Non-heart } \\
\text { beating donors }\end{array}$ & & 1 \\
\hline
\end{tabular}




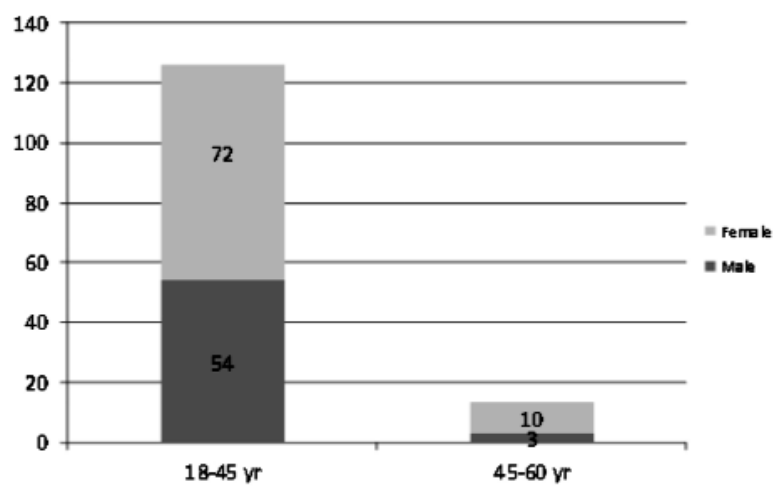

Figure 7. Age and gender distribution of living donors

\section{Living Donors}

The median age was 33 yrs (mean 34; range 19-53), and male/female ratio was $57 / 82$. Donor blood types were as follows: $51 \mathrm{pts}$ were OI (36.4\%), 60 pts were AII (43\%), 22 pts were BIII (15.7\%), and 7 pts were ABIV (5\%). The majority of living donors were in the $18-45 \mathrm{yr}$ age group $(\mathrm{N}=117)$, with a male/female ratio of 48/66 (Fig. 7). Major complication rate was $1.4 \%$ ( $2 \mathrm{pts}$ ), the re-intervention rate was the same $1.4 \%$ (2 pts), and mortality was nil.

\section{Liver Transplantation}

\section{Indications}

Main LT indications were HBV cirrhosis (230

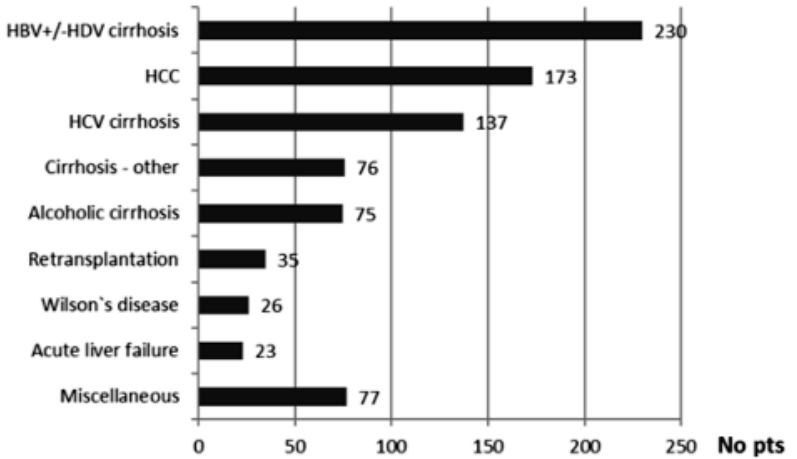

Figure 8. Indication for LT in the overall group

pts; $28.2 \%)$, HCC (173 pts; $21.2 \%$ ), and HCV cirrhosis (137 pts; 16.8\%) (Fig. 8); the other causes of cirrhosis and miscellaneous indications are presented in detail in Figs. 10 and 11. Fig. 9 shows the evolution of LT indications over times; particularly, the incidence of VHB-related cirrhosis decreased in favor of VHC-related cirrhosis. In case of LT for HBV-related cirrhosis, HDV co-infection was present in 159 out of 230 pts (68.7\%). In 22 out of the 137 pts (16.1\%) with LT for HCV-related cirrhosis, HBV infection was also present. Among the $128 \mathrm{pts}$ with HCC, $109 \mathrm{pts}$ were within Milan Criteria (63\%).

In adult recipients $(\mathrm{N}=753)$, the main indications were HCC (172 pts, $22.8 \%$ ), HBVrelated cirrhosis (166 pts, 22\%), and $\mathrm{HCV}^{-}$

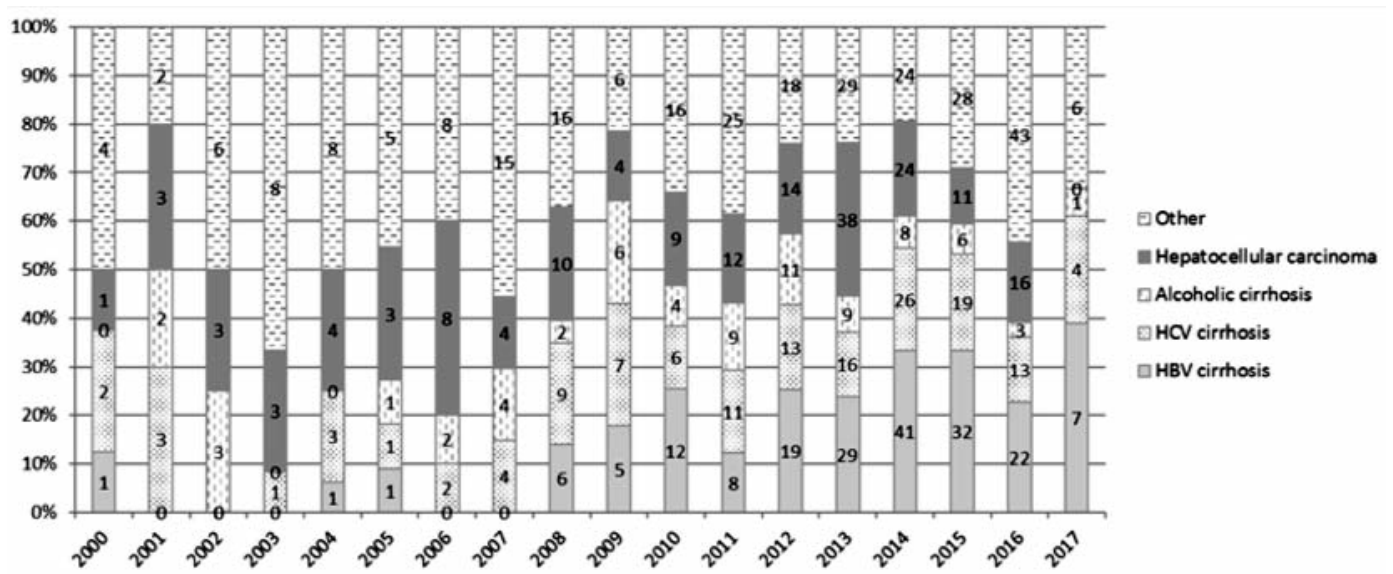

Figure 9. Evolution of main indications for LT in the overall group 


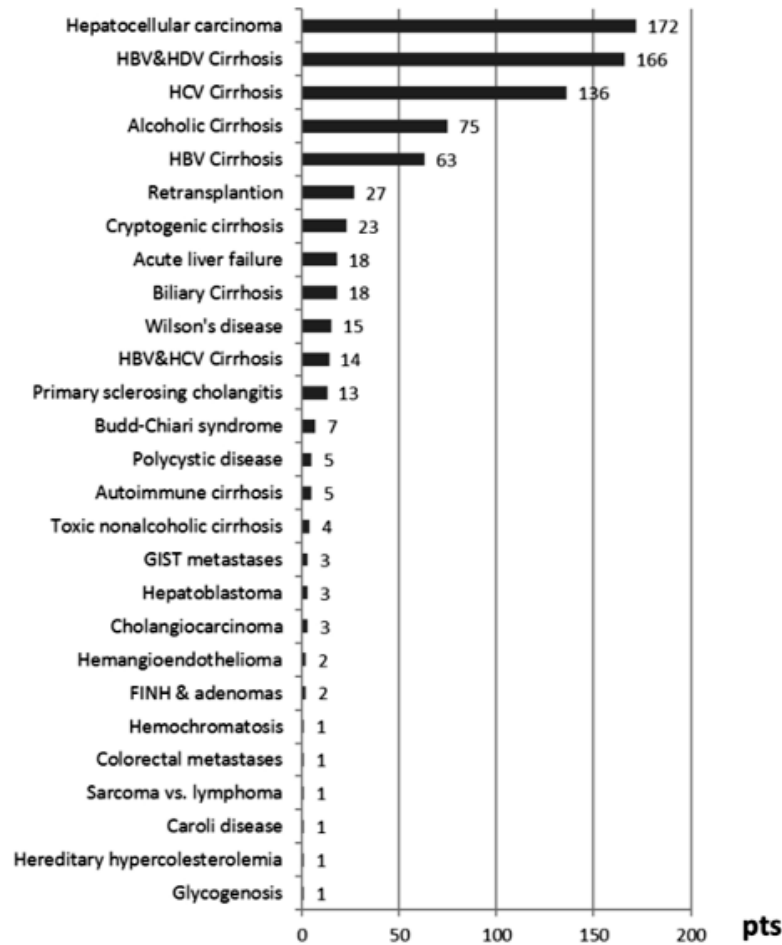

Figure 10. Indication for $L T$ in adult patients

related cirrhosis (136 pts, 18.1\%) (Fig. 10). In pediatric patients $(\mathrm{N}=64)$, the main indication for transplantation were congenital biliary anomalies (biliary atresia, hypoplasia or ductopenia) (12 pts; 16.7\%), Wilson's disease (11 pts; 15.3\%), glycogenosis (8 pts; 11.1\%), and congenital liver fibrosis (8 pts; 11.1\%) (Fig. 11).

\section{Technical Aspects}

In the overall group (817 pts), the DDLT was performed in $715 \mathrm{pts}(83.5 \%)$ and LDLT in 135 pts $(16.5 \%)$. The DDLT were whole organ LT (662 pts; 80.9\%), split graft LT (17 pts; 2.3\%), reduced graft LT (2 pts; $0.2 \%$ ), and domino LT (1 pt; 0.1\%) (Fig. 12). Split graft LT was performed with left lateral section in $6 \mathrm{pts}$, left hemiliver in $2 \mathrm{pts}$, right hemiliver in $2 \mathrm{pts}$, and right extended hemiliver in $7 \mathrm{pts}$. In particular, domino LT was performed for HCC on cirrhosis using a whole liver harvested from a living donor with homozygous familial hypercholesterolemia, who received in turn a split LT with right extended hemiliver (19). LDLT was

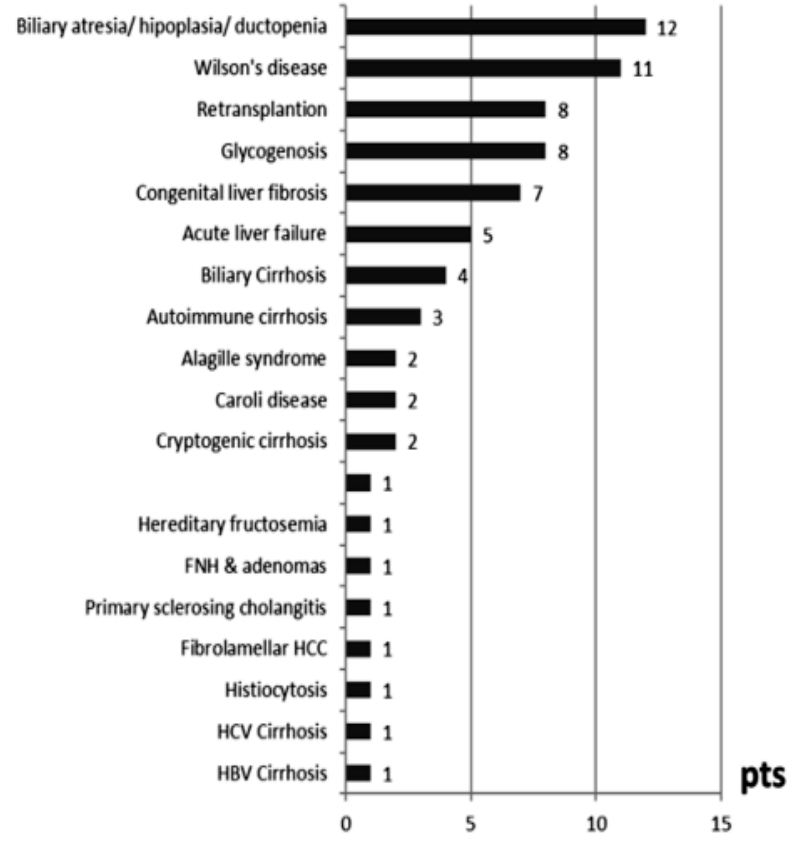

Figure 11. Indications for LT in pediatric patients

performed with right hemiliver in 93 pts (11.4\%), left lateral section in $28 \mathrm{pts}(3.4 \%)$, left hemiliver in 8 pts $(1 \%)$, left hemiliver with segment 1 in 4 pts $(0.5 \%)$, and dual graft LDLT in $2 \mathrm{pts}(0.2 \%)$. In particular, dual graft LDLT

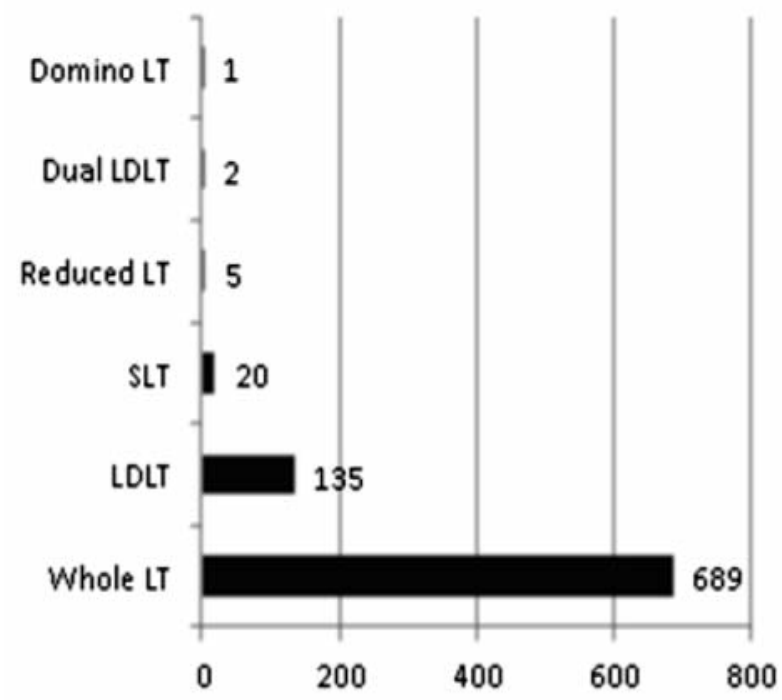

Figure 12. Surgical techniques used for LT in the overall group. 
Table 2. Comparative operative parameters of recipients of deceased (DDLT) and living (LDLT) donor liver transplantation

\begin{tabular}{lcc}
\hline Parameters & $\begin{array}{c}\text { DDLT } \\
\text { (N=715) }\end{array}$ & $\begin{array}{c}\text { LDLT } \\
\text { (N=137) }\end{array}$ \\
\hline Age (year) & $41 \pm 17$ & $34 \pm 21$ \\
\hline Gender (M/F) & $451 \pm 254$ & $57 \pm 82$ \\
\hline Operative time (min) & $377 \pm 98$ & $252 \pm 260$ \\
\hline Cold ischemia time (min) & $343 \pm 115$ & $82 \pm 101$ \\
\hline Warm ischemia time (min) & $35 \pm 26$ & $22 \pm 31$ \\
\hline Blood loss (l) & $5,7 \pm 8,3$ & $6,4 \pm 10,8$ \\
\hline
\end{tabular}

was performed in 2 cases: one received a right hemiliver and a left lateral section (18), and one received a left hemiliver and a left lateral section.

Technical aspects (operative time, cold ischemia time, warm ischemia time, and intraoperative blood loss) of DDLT and LDLT procedures are resumed in Table 2.

\section{Results}

Overall major morbidity rate (at least DindoClavien class IIIB) was $29.4 \%$ (254 out of 852 LTs); in DDLT and LDLT, major morbidity rates were $25.9 \%$ (185 out of $715 \mathrm{LTs}$ ) and $50.4 \%$ (69 out of $137 \mathrm{LTs}$ ), respectively $(p<0.01)$. In the 3 historical groups, major morbidity rates were $49 \%$ (47 out of 100 LTs) in Group 1, 42\% (66 out of 157 pts) in Group 2, and $23.7 \%$ (141 out of 595 pts) in Group 3 (p = $0.025)$.

Overall retransplantation rate was 4.3\% (35 pts); in DDLT and LDLT, retransplantation rates were $3.2 \%(22 \mathrm{pts})$, and 9.6\% (13 pts), respectively $(\mathrm{p}<0.01)$. The techniques used in retransplantation were: 27 whole graft LTs, 3 reduced graft LTs, 3 split graft LTs (2 with left lateral section, and 1 with right hemiliver), and 2 LDLT (with left lateral section).

Overall perioperative mortality rate was 8\% (65 out of $817 \mathrm{pts}$ ). In DDLT and LDLT, perioperative mortality rates were $6.4 \%$ (45 out of $705 \mathrm{pts}$ ) and $14.8 \%$ (20 out of $135 \mathrm{pts}$ ), respectively $(p=0.024)$.

Median follow-up was 29.5 months (mean 42, range 1-202). Long-term overall 1-, 3-, and 5-year estimated survival rates for patients were $87.9 \%, 81.5 \%$, and $78.8 \%$. Long-term $1^{-}, 3$, and 5-year estimated survival rates in function of gender were $89.5 \%, 80.9 \%$, and $77.9 \%$ (males), and $87.5 \%, 84.3 \%$, and $83.6 \%$ (females), respectively $(\mathrm{p}=0.21)$. In pediatric patients, longterm 1-, 3-, and 5-year estimated survival rates were $90.7 \%, 86.5 \%$, and $79.6 \%$ (0-17 yrs), while for adults were $87.6 \%, 81 \%$, and $79.2 \%(\mathrm{p}=0.6)$.

In what LT indications are concerned, longterm 1-, 3-, and 5-year estimated survival rates in HBV-related cirrhosis were $93 \%, 90.2 \%$, and $88.3 \%$, in HCV-related cirrhosis were $82.7 \%$, $78.4 \%$, and $76.4 \%$, in alcoholic cirrhosis were $90.6 \%, 84.5 \%$, and $79.8 \%$, while in HCC were $86.6 \%, 62.6 \%$, and $65.1 \%$, respectively $(\mathrm{p}=$ 0.002) (Fig. 13).

In the 3 studied groups, long-term 1-, 3-, and 5-year estimated survival rates were 69.6.1\%, 65.2\%, and 64.1\% (Group 1), 85.2\%, $78.5 \%$, and $74.5 \%$ (Group 2), and $81.7 \%$, $75.6 .2 \%$, and $74.8 \%$ (Group 3), respectively $(\mathrm{p}=0.042)($ Fig. 14)

\section{Discussion}

LT is a well-established therapeutic option that has proved its effectiveness by long postoperative survival (longest survival recorded is 42.7 years) and good quality of life (20).

The number of LT procedure constantly

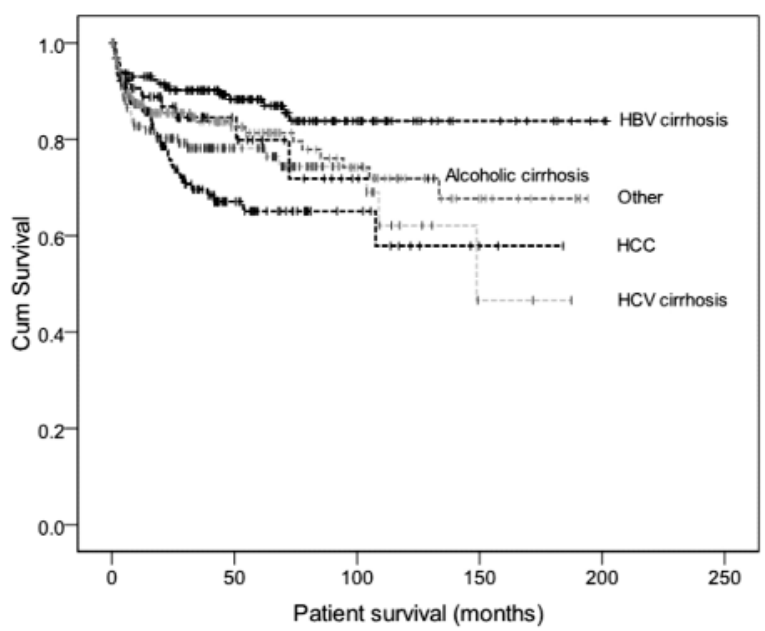

Figure 13. Long-term survival according to the indications for liver transplantation $(\mathrm{LT})(\mathrm{p}=0.002)$ 


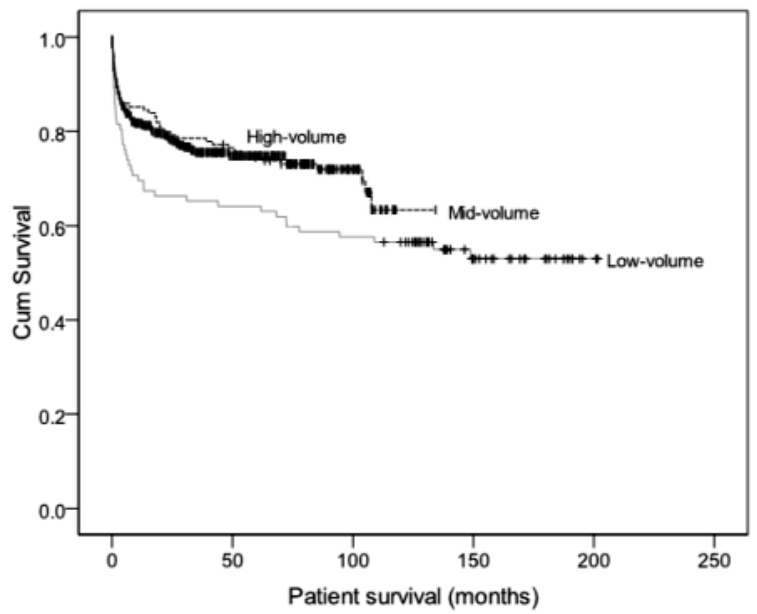

Figure 14. Patient survival during the 3 periods of the main center development (low-, mid-, and high-volume center) $(p=0.084)$

increases worldwide (23,986 LTs reported in 2012) as well as in Europe (7,173 LTs reported in 2013) (21). In Romania, the LT program was started as a stringent necessity in 2000 , while in Europe over 4,500 procedures were recorded that year and almost 45,000 overall. Among Eastern European countries, Romania has a well-developed program of liver transplantation (22), being the third (5.6 pmp), after Croatia (26.7 pmp, the highest in Europe) and Poland (8.8 pmp), being also the third as population number (21.3 million), after Ukraine (45.6 million) and Poland (38.5 million) (21).

\section{Waiting List}

The LT waiting list has grown continuously over the past decade in the context of a profound organ shortage, with consequent increased mortality rate on the waiting list, prolonged waiting time, and lack of emergency LT supply $(8,9)$. Approximately $10, .000$ patients are added each year on the waiting list in US, with around 15,000 patients still on waiting list by the end of the given year. In Romania, 141 patients were enrolled on the waiting list in 2016 , with around 550 still on waiting list by the end of the year (10). One-year overall mortality on waiting list decreased significantly over time from $31.4 \%$ (before 2011) to $11.8 \%$ (after 2011).
Despite the progressive increase in the number of LTs, the mortality on the waiting list remains between 5\%-10\% worldwide (8) and $11.8 \%$ in Romania, and patients have to deal with long waiting periods. Our main goal was to continuously reduce the drop-out rate on waiting list (due to mortality and morbidity) by shortening the waiting time for LT insured by providing the necessary grafts, including for urgent LT (acute liver failure and emergency re-transplantation).

\section{Organ Donation}

Cadaveric donors account for the majority of liver grafts (over 90\% in Europe and China), but this source is severely constrained due to social, cultural or legal factors. Consequently, the donation rates vary from $35.3 \mathrm{pmp}$ in Spain (highest worldwide), to $25.8 \mathrm{pmp}$ in US, $19.5 \mathrm{pmp}$ in Europe (21), and less than $8 \mathrm{pmp}$ in Asia (23). Among Eastern European countries, Romania occupies the Vth place, with a donation rate of $6.1 \mathrm{pmp}$ (21). About 75$80 \%$ of donors provide a liver for LT.

During early 1990s, severe cerebral trauma due to traffic accidents was the main cause of death for donors worldwide. In contrast, in the recent years, this cause of death significantly decreased, being replaced by stroke. A similar trend was noted in Romania, with a decrease of trauma incidence from $61.2 \%$ in Group 1 (41 out of 67 deceased donors) to $35.6 \%$ in Group 3 (181 out of 508 deceased donors) ( $\mathrm{p}=0.001)$, and a concomitant increase of stroke incidence from 34.3\% in Group 1 (23 out of 67 deceased donors) to $52.2 \%$ in Group 3 (265 out of 508 deceased donors) $(p=0.023)$,

According to international statistics, Spain and Italy are the European countries with the highest percentage of over 70 year donors, representing over $20 \%$ of total donors registered in these two countries (24). In Romania, donors over 65 yrs were avoided, but were accepted over time (1.5\% and $7.1 \%$ in Group 2 and 3 , respectively).

Even though criteria for marginal donors vary from center to center, the use of extended criteria grafts has become a common policy 
worldwide due to organ scarcity. Moreover, the limits of extended criteria are constantly pushed, and organs that were previously considered unacceptable are nowadays used. However, the association of multiple marginal features seems to have a negative impact on graft function and should therefore be avoided (25). Development and implementation of methods to avoid and/or treat the ischemia/ reperfusion graft injuries represents the key to further push the limits of extended criteria while improving the LT outcome (26).

Additional sources for liver grafts, such methanol-poisoned donors (27), grafts with trauma lesions or benign tumors and other rare conditions such Takayasu's syndrome, even though relatively scarce, represents a source for grafts that should not be neglected.

Recently, there has been a steady increase of living donors worldwide, mainly due to the lack of deceased donors, a similar trend being recorded in Romania: Group 3 included 58.4\% (80 pts) of all 137 LDLT, while Group 1 and 2 included only $21.9 \%$ (30 pts), and $19.7 \%$ (27 pts), respectively.

\section{Liver Transplantation}

Recipient's age has increased during this period of time. As a result, in the last decade, around $30 \%$ of the pool of recipients both on the waiting list and finally transplanted were over 60 years old. Elderly recipients may benefit from a senescent immune system, with consequent decreased requirements for immunosuppression, and possibly lower rate of acute allograft rejection. Despite good overall short-term survival in the elderly, long-term survival may be worse because of an increased rate of longterm complications not necessarily related to transplantation, such as malignancy and vascular disease (28). In Romania, the recipient's age increased during the analyzed period, in accordance with the literature data: the mean age in Group 3 was significantly higher than the one in Group 1 (48 yrs vs 43 yrs, respectively; $\mathrm{p}=0.044)$. Overall, $21.6 \%$ of the pool of recipients (90 pts) was over 60 years old.

Since the first successful DDLT performed by Starzl TE (USA) in 1967 (29), whole organ LT still remains the main procedure in $\mathrm{LT}$, but the need to increase the number of transplanted patients involves the implementation of other techniques, such as LDLT, split graft LT, and domino LT.

Even though LDLT was first described in 1969 (30), it was introduced in clinical practice much later, in 1989 by Broeschl et al (USA) (31), Strong et al (Australia) (32) and Raia et al (Brasil) (33), representing one of the most remarkable steps in the field of LT. It involves an unique source of grafts because the liver is directed to only one specific candidate, with no need for an allocation system. In Europe, LDLT represents only $3.6 \%$ (21) of all LT procedures, while in US - $21.5 \%$ (34), and in Asia (except China) - over 90\% (35). For pediatric patients, LDLT has become the main source of donors, while in adults represents a good indication in selected cases. Advantages of LDLT include the ability to be performed on an elective basis, with optimal timing and no waiting time for the recipient, the graft is in excellent condition (preselected graft, healthy donor), with short ischemic time, while the indications for transplantation may be extended (i.e. HCC beyond Milan criteria). As disadvantages, LDLT has donor mortality, even though as low as $0.5-1 \%$ (36) (37), high rate of vascular (5-15\%) and biliary (10-30\%) complications for both donor and recipient, and risk of small-for-size syndrome (38). Even though postoperative complication rate may be higher in case of LDLT, with proper treatment the long-term outcome may be similar in comparison with DDLT (39). Although complex and expertise demanding, dual graft LDLT has proven to be a safe procedure and a feasible solution to overcome the risk of small-for-size graft syndrome, when the selection of an optimal single donor fails $(18,40)$. Even though only 2 cases were performed in our experience, it remains part of our strategy to increase the number of LTs.

Split graft LT involves graft with normal anatomy and no risk factors for compromised liver function. Currently, split LT accounts for about $5 \%$ of total LTs, but about $20 \%$ of donors 
are potential candidates, hence the necessity of proper identification and harvest (41). Insitu split LT may provide comparable longterm survival results with those for whole liver LT, even though with a higher incidence of biliary and vascular complications (42). The drawbacks of ex-vivo split LT include timeconsuming procedure, prolonged cold ischemia time, increased inflammatory response on reperfusion, poor function of the graft, while for in-situ split LT the disadvantages are prolonged procurement time and need for more experienced surgeons.

Domino LT, although rare, remains a viable alternative in selected cases with hereditary metabolic disease, such as familial amyloidotic polyneuropathy and homozygous familial hypercholesterolemia $(19,43,44,45)$.

In our experience, the results after LT continuously improved over time, in terms of operative parameter (cold and warm ischemia time, operative time and blood loss), major morbidity and postoperative results. The major complication rate decreased significantly over time, from $47 \%$ during the low-volume center period to $23.7 \%$ in the high-volume center period $(p=0.029)$. The perioperative mortality also decreased significantly over time, from $11 \%$ during the stage of low-volume center to $7.1 \%$ in the phase of high-volume center. The long-term overall 1-, 3-, and 5-year estimated survival rates for patients in our experience (87.9\%, 81.5\%, and $78.8 \%$, respectively) were similar to other centers (46). The long-term results also improved over time, a significant improvement being observed during mid- and high-volume center period when compared to low-volume center period, with $1^{-}, 3^{-}$, and $5^{-}$ year estimated survival rates of $69.6 .1 \%$, $65.2 \%$, and $64.1 \%$ (Group 1), 85.2\%, 78.5\%, and $74.5 \%$ (Group 2), and 81.7\%, 75.6.2\%, and $74.8 \%$ (Group 3), respectively $(\mathrm{p}=0.042)$.

In order to increase the number of LTs, our main strategy was to increase the donor pool by optimizing the laws for organ donation, training the medical professionals (European funded educational program for doctors since 2007), mass education (Orthodox Church recognition in 2000, Romanian Association of transplanted patients since 2010, national TV educational campaign in 2013), and by improving the donor hospital efficiency (transplant coordinators and key donation persons implementation in 2012). Furthermore, the use of existing deceased donors was maximized by means of ECD grafts and use of other sources for liver grafts, such as poisoned donors (methanol) and grafts with particular lesions (trauma, benign tumors, etc.). Technical variant grafts, such LDLT, split LT, dual graft LT and domino LT, were also used in order to further increase the number of LTs.

\section{Conclusion}

The Romanian National program for liver transplantation addresses all causes of acute and chronic liver failure or liver tumors in adults and children, using all surgical techniques, with good long-term outcome. All available strategies were used in order to extend the donor pool and increase the number of LTs, such as pushing the limits of the extended criteria for deceased donors, implementing the Split LT, domino LT, LDLT, and dual graft LDLT. Proper donor-recipient matching is the key for the optimal use of marginal and surgical variant grafts.

Multidisciplinarity is the main feature of a LT program, that involves many disciplines like surgery, imaging, endoscopy, interventional radiology, microbiology, pathology, psychology, etc.

Opening the new LT programs was justified when the main program (at "Fundeni”" Institute) has reached its limits.

The program constantly increased over time, leading to less time and lower mortality rate on the waiting list. New challenges are to be faced in order to maintain and to further develop this program, in the context of political and economic crisis.

\section{Source of funding}

No source of support for the present work. 


\section{References}

1. Kim WR, Stock PG, Smith JM, Heimbach JK, Skeans MA, Edwards EB, et al. OPTN/SRTR 2011 annual data report: liver. Am J Transplant 2013;13(suppl 1):73-102.

2. Popescu I, Tulbure D, Ionescu M, Vasile R, Baila S, Ciurea S, et al. Liver transplantation--considerations over 8 cases operated in the year 2000. Chirurgia (Bucur). 2001:96(5):453-67.

3. Edwards EB, Roberts JP, McBride MA, Schulak JA, Hunsicker LG. The effect of the volume of procedures at transplantation centers on mortality after liver transplantation. N Engl J Med. 1999;341(27):2049-53.

4. Axelrod DA, Kalbfleisch JD, Sun RJ, Guidinger MK, Biswas P, Levine GN, et al. Innovations in the assessment of transplant center performance: implications for quality improvement. Am J Transplant. 2009;9(4 Pt 2): 959-69. doi: 10.1111/j.1600-6143.2009.02570.x.

5. McMillan RW, Uppot R, Zibari GB, Aultman DF, Dies DF, McDonald JC. Can low volume liver transplant centers be successful? The Regional Transplant Center of Willis-Knighton \& Louisiana State University Medical Center. The first 120 liver transplants. J La State Med Soc. 1999;151(7):367-72.

6. Guba M. Center volume, competition, and outcome in German liver transplant centers. Transplant Res. 2014;3(1):6.

7. Mazzaferro V, Regalia E, Doci R, Andreola S, Pulvirenti A, Bozzetti F, et al. Liver transplantation for the treatment of small hepatocellular carcinomas in patients with cirrhosis. N Engl J Med. 1996;334(11):693-9.

8. Dindo D, Demartines N, Clavien PA. Classification of surgical complications: a new proposal with evaluation in a cohort of 6336 patients and results of a survey. Ann Surg. 2004;240(2):205-13.

9. lacob S, Gheorghe L, lacob R, Gheorghe C, Hrehoret D, Popescu I. MELD exceptions and new predictive score of death on long waiting lists for liver transplantation. Chirurgia (Bucur). 2009;104(3):267-73.

10. Gheorghe L, lacob S, lacob R, Smira G, Pietrareanu C, Hrehoret D, et al. Dynamics of the Romanian waiting list for liver transplantation after changing organ allocation policy. J Gastrointestin Liver Dis. 2013; 22(3):299-303.

11. Mazzaferro V, Regalia E, Doci R, Andreola S, Pulvirenti A, Bozzetti F, et al. Liver transplantation for the treatment of small hepatocellular carcinomas in patients with cirrhosis. N Engl J Med. 1996;334(11):693-9.

12. Popescu I, (sub redactia). Transplantul Hepatic. Bucuresti: Ed Academiei; 2011.

13. Durand F, Renz JF, Alkofer B, Burra P, Clavien PA, Porte RJ, et al. Report of the Paris consensus meeting on expanded criteria donors in liver transplantation. Liver Transpl. 2008;14(12):1694-707.

14. lacob S, Cicinnati VR, Hilgard P, lacob RA, Gheorghe LS, Popescu I, et al. Predictors of graft and patient survival in hepatitis $\mathrm{C}$ virus (HCV) recipients: model to predict HCV cirrhosis after liver transplantation. Transplantation. 2007;84(1):56-63.

15. Gheorghe L, lacob S, Popescu I. Living donor liver transplantation and hepatitis C. Rom J Gastroenterol. 2004;13(4):317-27.

16. Popescu I. Living donor liver transplantation for hepatocellular carcinoma: defining criteria to extend indications. Dig Dis Sci. 2009; 54(2):199-200.

17. Popescu I, Ionescu M, Brasoveanu V, Hrehoret D, Matei E, Dorobantu $\mathrm{B}$, et al. Liver transplantation--indications, surgical technique, results-the analysis of a clinical series of 200 cases. Chirurgia (Bucur). 2010; 105(2):177-86.

18. Botea F, Brasoveanu V, Constantinescu A, Ionescu M, Matei E, Popescu I. Living donor liver transplantation with dual grafts -- a case report. Chirurgia (Bucur). 2013;108(4):547-52.

19. Popescu I, Simionescu M, Tulbure D, Sima A, Catana C, Niculescu L, et al. Homozygous familial hypercholesterolemia: specific indication for domino liver transplantation. Transplantation. 2003;76(9):1345-50.

20. Starzl TE. The long reach of liver transplantation. Nature medicine. 2012;18(10):XIX-XII.

21. European Committee (partial agreement) on organ transplantation. International figures on organ, tissue \& hematopoietic stem cell donation \& transplantation activities. Year 2013. Editor Rafael Matesanz. Newsletter Transplant. 2014;19(1):1-96.

22. Popescu I, Ionescu M, Brasoveanu V, Hrehoret D, Botea F, Dorobantu et al. Building a liver transplant program in a resource limited country: a 15-year retrospective analysis of 648 patients operated in the Romanian National Program. J. Transl. Med. Res 2015;20(2):55-66.

23. Siriwardana R.C, Lo C.M. Living donor liver transplant in Asia - trials and tribulations . Sri Lanka J Surg, 2011;29(1):4-6.

24. Matesanz R, de la Rosa G. Liver transplantation: The Spanish experience. Digestive and Liver Disease Supplements 2009; 3:75-81.

25. Busuttil RW, Tanaka K. The utility of marginal donors in liver transplantation. Liver Transpl. 2003:9(7):651-63.

26. Jiménez-Castro MB, Elias-Miró M, Peralta C. Expanding the Donor Pool in Liver Transplantation: Influence of Ischemia-Reperfusion. In: Organ Donation and Organ Donors. Nova Science Publishers, Inc. 2013.

27. Zota V, Popescu I, Ciurea S, Copaciu E, Predescu O, Costandache F, et al. Successful use of the liver of a methanol-poisoned, brain-dead organ donor. Transpl Int. 2003;16(6):444-6.

28. Keswani RN, Ahmed A, Keeffe EB. Older age and liver transplantation: a review. Liver Transpl. 2004:10(8):957-67.

29. Starzl TE, Iwatsuki S, Van Thiel DH, Gartner JC, Zitelli BJ, Malatack JJ, et al. Evolution of liver transplantation. Hepatology. 1982;2(5):614-36.

30. Smith B. Segmental liver transplantation from a living donor. J Pediatr Surg. 1969;4(1):126-32.

31. Broelsch CE, Emond JC, Whitington PF, Thistlethwaite JR, Baker AL, Lichtor JL. Application of reduced-size liver transplants as split grafts, auxiliary orthotopic grafts, and living related segmental transplants. Ann Surg. 1990; 212(3):368-75; 375-7.

32. Strong RW, Lynch SV, Ong TH, Matsunami H, Koido Y, Balderson GA. Successful liver transplantation from a living donor to her son. N Engl J Med. 1990;322(21):1505-7.

33. Raia S, Nery JR, Mies S. Liver transplantation from live donors. Lancet. 1989;2(8661):497.

34. Organ Procurement and Transplantation Network. National Data Reports 2014. http://optn.transplant.hrsa.gov/converge/latestData/ step2.asp.

35. de Villa V, Lo CM. Liver transplantation for hepatocellular carcinoma in Asia. Oncologist. 2007;12(11):1321-31.

36. Chan SC, Liu CL, Lo CM, Lam BK, Lee EW, Fan ST. Donor quality of life before and after adult-to-adult right liver live donor liver transplantation. Liver Transpl 2006; 12: 1529-1536.

37. Salah T, Sultan AM, Fathy OM, Elshobary MM, Elghawalby NA, Sultan $A$, et al. Outcome of right hepatectomy for living liver donors: a single Egyptian center experience. J Gastrointest Surg 2012; 16: 1181-1188.

38. Middleton P, Duffield M, Lynch S, Padbury RT, House T, Stanton P, et al. Living donor liver transplantation-Adult donor outcomes: A systematic review. Liver Transplantation 2005;12(1):24-30.

39. Wan P, Zhang JJ, Li QG, Xu N, Zhang M, Chen XS, et al. Living-donor or deceased-donor liver transplantation for hepatic carcinoma: a casematched comparison. World J Gastroenterol. 2014;20(15):4393-400.

40. Lee S, Hwang S, Park K, Lee Y, Choi D, Ahn C, et al. An adult-to-adult living donor liver transplant using dual left lobe grafts. Surgery. 2001; 129(5):647-50.

41. deLemos AS, Vagefi PA. Expanding the donor pool in liver transplantation: extended criteria donors. Clinical Liver Disease. 2013;2(4):156159 .

42. Vagefi PA, Parekh J, Ascher NL, Roberts JP, Freise CE. Outcomes with split liver transplantation in 106 recipients: the University of California, San Francisco, experience from 1993 to 2010. Arch Surg. 2011; 146(9):1052-9. doi: 10.1001/archsurg.2011.218.

43. Popescu I, Habib N, Dima S, Hancu N, Gheorghe L, lacob S, et al. Domino liver transplantation using a graft from a donor with familial hypercholesterolemia: seven-yr follow-up. Clin Transplant. 2009;23(4): 565-70.

44. Popescu I, Dima SO. Domino liver transplantation: how far can we push the paradigm? Liver Transpl. 2012;18(1):22-8.

45. Liu C, Niu DM, Loong CC, Hsia CY, Tsou MY, Tsai HL, et al. Domino liver graft from a patient with homozygous familial hypercholesterolemia Pediatr Transplant. 2010;14(3):E30-3.

46. Adam R, Karam V, Delvart V, O'Grady J, Mirza D, Klempnauer J, et al. Evolution of indications and results of liver transplantation in Europe. A report from the European Liver Transplant Registry (ELTR). J Hepatol. 2012;57(3):675-88. doi: 10.1016/j.jhep.2012.04.015. 